\title{
Development of Diagnostic Technology of Xylella fastidiosa Using Loop-Mediated Isothermal Amplification and PCR Methods
}

\author{
*Corresponding author \\ Tel: +82-54-912-0675 \\ Fax: +82-54-912-0688 \\ E-mail: arj9095@korea.kr \\ ORCID \\ https://orcid.org/0000-0002-0560-4714
}

Received November 10, 2020

Revised March 24, 2021

Accepted March 26, 2021

\author{
Suyoung Kim, Yujin Park, and Gidon Kim*(i) \\ Plant Quarantine Technology Center, Animal and Plant Quarantine Agency, Gimcheon 39660, Korea
}

\begin{abstract}
Xylella fastidiosa is the most damaging pathogen in many parts of the world. To increase diagnostic capability of $X$. fastidiosa in the field, the loop-mediated isothermal amplification (LAMP) and polymerase chain reaction (PCR) assay were developed to mqsA gene of citrate-synthase (XF 1535) X. fastidiosa and evaluated for specificity and sensitivity. Both assays were more robust than current published tests for detection of $X$. fastidiosa when screened against 16 isolates representing the four major subgroups of the bacterium from a range of host species. No cross reaction with DNA from healthy hosts or other species of bacteria has been observed. The LAMP and PCR assays could detect $10^{-4} \mathrm{pmol}$ and 100 copies of the gene, respectively. Hydroxynaphthol blue was evaluated as an endpoint detection method for LAMP. There was a significant color shift that signaled the existence of the bacterium when at least 100 copies of the target template were present.
\end{abstract}

Keywords: Diagnostic, Loop-mediated isothermal amplification, PCR, Xylella fastidiosa

\section{Introduction}

Xylella fastidiosa (Wells et al., 1987) is a pathogen of bacterial plants that cause many economically significant diseases, including grapevine disease of Pierce, citrus veinal chlorosis, almond leaf scorch, phony peach, and leaf scorch on a range of ornamental plants and shade trees (Hopkins and Purcell, 2002). X. fastidiosa is a globally regulated and banned pathogen. Leafhoppers of the subfamily Cicadellinae (Hemiptera: Cicadellidae) and spittle bugs or frog hoppers of the family Cercopidae (Hemiptera) are the most common known vectors (Purcell, 1997). The distribution of $X$. fastidiosa is usually restricted to the Americas (Purcell, 1997), with two exceptions, in Vitis vinifera in Kosovo (Berisha et al., 1998) and pear in Taiwan (Leu, 1993). X. fastidiosa is known to be vulnerable to low temperatures, which has confined its movement to

Research in Plant Disease

pISSN 1598-2262, elSSN 2233-9191

www.online-rpd.org regions with temperate climates and, in particular, to cold winters (Purcell, 1997). Many colder parts of the world, however, have one or more vector species, such as the spittlebug (Philaenus spumarius), so there is a possibility for $X$. fastidiosa to spread to such areas if strains are cold-tolerant, such as almond leaf scorch, become established (Purcell, 1997). From a quarantine viewpoint, the main aspect of any exclusion technique is rapid identification and diagnosis. Present $X$. fastidiosa diagnostic tests include bacterial cell culture, traditional polymerase chain reaction (PCR) (Huang, 2009; Huang et al., 2006; Minsavage et al., 1994; Pooler and Hartung, 1995; Rodrigues et al., 2003) and real-time PCR (Francis et al., 2006; Schaad et al., 2002). While many of these methods have been widely used in the laboratory, most of these methods are not readily transferable to the field. In addition, the PCR assay was developed over 15 years ago. When the $X$. fastidiosa DNA sequence was little usable, this assay is widely used for quarantine screening and, thus, checking that it reliably detects all isolates of the bacterium is especially essential. Alternative methods of detection have been considered in 
light of these factors. Loop-mediated isothermal amplification (LAMP) is one approach that has recently been implemented for plant pathogen diagnostics. It can be done in a heat block or water bath because the LAMP reaction is isothermal, thereby reducing the need for specialized equipment. Moreover, colorimetric or fluorescent dyes may be observed for positive amplification (Goto et al., 2009; Tomlinson and Boonham, 2008), removing the need to run gels. Both of these factors lead to the field's transferability. The production and evaluation of a LAMP assay for $X$. fastidiosa is presented here in order to improve diagnostic capacity by allowing surveillance activities, improving response times during incursions, and enabling testing at the border for imported goods. During the development of the LAMP assay, the potential for developing PCR was based on the identification of the same region used for the LAMP primer design. A new PCR assay was also tested in accordance with the LAMP process.

\section{Materials and Methods}

Samples. X. fastidiosa DNA (ATCC 700964D-5, ATCC 35881D, ATCC 35881D-5) were obtained from commercial sources (American Type Culture Collection, Manassas, VA, USA). Control strains for specific diagnostic were obtained from commercial sources (Korea Agricultural Culture Collection, Suwon, Korea).

PCR primer design and PCR condition. PCR primers are the method to diagnose a large number of samples quickly, and fast and accurate diagnostics can be made without

Table 1. Sequence of PCR primers for Xylella fastidiosa used in this study

\begin{tabular}{|c|c|c|c|c|c|}
\hline Primer & Sequence (5'-3') & Size & Host & Target & Reference \\
\hline RST31 & GCGTTAATITCGAAGTGATTCGA & \multirow[t]{2}{*}{733} & \multirow{2}{*}{$\begin{array}{l}\text { Grapevine, citrus, oak, red oak, } \\
\text { sycamore, plum, goldenrod }\end{array}$} & \multirow{2}{*}{$\begin{array}{l}7.4 \mathrm{~kb} \text { EcoR } 1 \\
\text { restriction fragment }\end{array}$} & \multirow{2}{*}{$\begin{array}{l}\text { Minsavage } \\
\text { et al. (1994) }\end{array}$} \\
\hline RST33 & CACCATTCGTATCCCGGTG & & & & \\
\hline$X F 1-F$ & CAGCACATTGGTAGTAATAC & \multirow[t]{2}{*}{387} & \multirow{2}{*}{$\begin{array}{l}\text { Grapevine, almond, plum, } \\
\text { American elm, citrus }\end{array}$} & \multirow[t]{2}{*}{$16 \mathrm{~S}$ rDNA } & \multirow{2}{*}{$\begin{array}{l}\text { Firrao and } \\
\text { Bazzi (1994) }\end{array}$} \\
\hline XF6-R & ACTAGGTATTAACCAATTGC & & & & \\
\hline 208-1 & ACGGCCGACCATTACTGCTG & \multirow[t]{2}{*}{320} & \multirow{2}{*}{$\begin{array}{l}\text { Citrus, grapevine, mulberry, } \\
\text { almond, plum, elm, oak, } \\
\text { ragweed, periwinkle }\end{array}$} & \multirow[t]{2}{*}{ RAPD fragment } & \multirow{4}{*}{$\begin{array}{c}\text { Pooler and } \\
\text { Hartung (1995) }\end{array}$} \\
\hline $208-2$ & ACGGCCGACCCGGAGTATCA & & & & \\
\hline XF176f & AAACAATCACAGGGGACTGC & \multirow[t]{2}{*}{511} & Citrus, mulberry, oak, & \multirow[t]{2}{*}{-} & \\
\hline XF686r & ATATTCATAGATTCCGTCGA & & (non-Pierce's disease) & & \\
\hline 0067-a-S-19 & CGGCAGCACATTGGTAGTA & \multirow[t]{2}{*}{1,348} & \multirow[t]{2}{*}{ Citrus, grapevine, mulberry } & \multirow[t]{2}{*}{$16 \mathrm{~S}$ rDNA } & \multirow{2}{*}{$\begin{array}{l}\text { Rodrigues et al. } \\
\qquad(2003)\end{array}$} \\
\hline 1439-a-A-19 & CTCCTCGCGGTTAAGCTAC & & & & \\
\hline G1 & GAAGTCGTAACAAGG & \multirow[t]{2}{*}{522} & \multirow{2}{*}{$\begin{array}{l}\text { Porcelain berry, } \\
\text { wild grape, mulberry }\end{array}$} & \multirow[t]{2}{*}{$16 \mathrm{~S}$ rDNA } & \multirow{2}{*}{$\begin{array}{l}\text { Huang and } \\
\text { Sherald (2004) }\end{array}$} \\
\hline L1 & CAAGGCATCCACCGT & & & & \\
\hline Teme150fc & TCTACCTTATCGTGGGGGAC & \multirow[t]{2}{*}{348} & \multirow[t]{2}{*}{ Almond } & \multirow[t]{2}{*}{$16 \mathrm{~S}$ rDNA } & \multirow{4}{*}{$\begin{array}{l}\text { Chen et al. } \\
\text { (2005) }\end{array}$} \\
\hline Teme454rg & ACAACTAGGTATTAACCAATTGCC & & & & \\
\hline XF2542-L & TTGATCGAGCTGATGATCG & \multirow[t]{2}{*}{412} & \multirow{2}{*}{$\begin{array}{l}\text { Grape, almond, spanish, } \\
\text { broom, Brassica spp. }\end{array}$} & \multirow[t]{2}{*}{ GeneXF2542 } & \\
\hline XF2542-R & CAGTACAGCCTGCTGGAGTTA & & & & \\
\hline $16 S-23 S F$ & GATGACTGGGGTGAAGTCGT & \multirow[t]{2}{*}{650} & \multirow{2}{*}{$\begin{array}{l}\text { Citrus, coffee, grapevine, } \\
\text { mulberry, almond elm, } \\
\text { ragweed, periwinkle }\end{array}$} & \multirow{2}{*}{$\begin{array}{l}\text { 16S-23S intergenic } \\
\text { spacer }\end{array}$} & \multirow{2}{*}{$\begin{array}{l}\text { Martinati et al. } \\
\qquad(2007)\end{array}$} \\
\hline $16 S-23 S R$ & GACACTITTCGCAGGCTACC & & & & \\
\hline Xfa-rpod-F4 & ACTGAGGTTGTCGTTGGCTT & \multirow[t]{2}{*}{988} & \multirow[t]{2}{*}{ Olive, citrus, coffee } & RNA polymerase & Bleve et al. \\
\hline Xfa-rpod-R4 & CCTCAGGCATGTCCATITCC & & & sigma-70 factor (rpoD) & (2016) \\
\hline mqsA-F & ATGCTTTACACCTATAAGC & 402 & Grapevine & Type II toxin-antitoxin & \\
\hline mqsA-R & ATCCAGAAGCTTGAATAACTT & & & $\begin{array}{c}\text { system MqsA family } \\
\text { antitoxin }\end{array}$ & \\
\hline
\end{tabular}

RAPD, random amplified polymorphic DNA. 


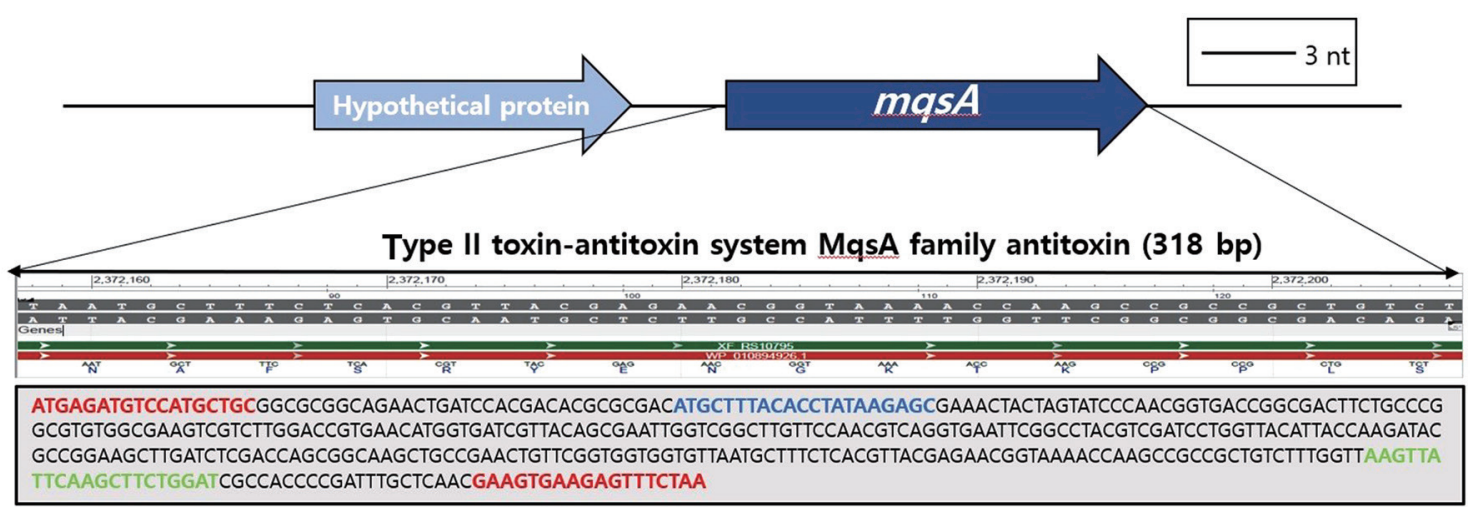

Fig. 1. $m q s A$ gene region for the diagnosis of Xylella fastidiosa. Target gene selection; masA directly binds to the toxin-antitoxin system operon and has a function to regulate operon self-expression. Blue text is mqsA-F primer; green text is mqsA-R primer.

complicated equipment. After exploring different gene sites linked to the diagnosis of $X$. fastidiosa, primers were therefore prepared after the optimal target gene was selected (Table 1). The mas $A$ gene sequence of the standard strain $X$. fastidiosa was used to prepare PCR primers (Fig. 1). For PCR, the primer is $20 \mathrm{pM}$ and AccuPower PCR premix (1 U Taq DNA polymerase, $250 \mu \mathrm{m}$ dNTP, $10 \mathrm{mM}$ Tris-HCl, $40 \mathrm{mM} \mathrm{KCl}, 1.5$ $\mathrm{mM} \mathrm{MgCl}$, stabilizer and tracking dye: Bioneer, Daejeon, Korea), template genomic DNA, a reaction solution with a total volume of $20 \mu \mathrm{l}$ was prepared (Francis et al., 2006). Initial denature ( 2 min at $94^{\circ} \mathrm{C}$ ), denature $\left(1 \mathrm{~min}\right.$ at $\left.94^{\circ} \mathrm{C}\right)$, annealing (1 min at $55^{\circ} \mathrm{C}$ ), extension ( $1 \mathrm{~min} 30 \mathrm{sec}$ at $72^{\circ} \mathrm{C}$ ) After reacting a total of $35 \mathrm{cycles}$, last extension $\left(5 \mathrm{~min}\right.$ at $\left.72^{\circ} \mathrm{C}\right)$, reaction was carried out (Fukuta et al., 2003). Thereafter, the product was subjected to electrophoresis at $50 \mathrm{~V}$ for $40 \mathrm{~min}$ using $1.5 \%$ agarose gel added with SYBR Green I and 1× TAE buffer, stained with ethidium bromide, and observed under UV illumination.
LAMP primer design. In order to design the LAMP PCR primer, the primer was designed by referring to the 10 kinds of 16S rDNA nucleotide sequences registered in GenBank. LAMP DNA oligonucleotide primer of $X$. fastidiosa is the BLAST program (Berisha et al., 1998). The following sequence was designed by selecting a primer for LAMP of $X$. fastidiosa using Primer Explorer version 3 (https:// www.primerexplorer.jp/lamp3.0.0/index.html), a LAMP primer designing software (Fukuta et al. 2003). In the primer set, the following two inner primers (forward inner primer [FIP], backward inner primer [BIP]) that can recognize six specific regions of the target sequence composed of four primers are the complementary nucleotide sequence of the $X$. fastidiosa sequence and loop. It was produced by combining the partial TIT spacer of the sequence forming the reverse transcription LAMP (Fukuta et al., 2003). The following two outer primers (F3: forward outer primer, B3: backward outer primer) were designed to be located outside the inner primer, respectively. A total of 6 primers were produced by ordering

Table 2. Sequence of LAMP primers for Xylella fastidiosa used in this study

\begin{tabular}{|c|c|c|c|c|}
\hline $\begin{array}{c}\text { Plant } \\
\text { disease }\end{array}$ & Target gene & $\begin{array}{c}\text { LOD } \\
\text { measured value }\end{array}$ & Oligo name & Sequence $\left(5^{\prime}-3^{\prime}\right)$ \\
\hline \multirow{6}{*}{$\begin{array}{c}\text { Xylella } \\
\text { fastidiosa }\end{array}$} & \multirow{6}{*}{$\begin{array}{l}\text { Citrate (Si)- } \\
\text { synthase } \\
\text { (XF1535) }\end{array}$} & \multirow[t]{6}{*}{$10^{-2}$} & F3 & CCATACATTCCCATTGAGCA \\
\hline & & & B3 & AGGTCTTGAGGTTGCCAA \\
\hline & & & $\mathrm{FIP}(\mathrm{F} 1 \mathrm{c}+\mathrm{F} 2)$ & GCTTTCACGAAGACCCTTCGTGAGTTCCTTCATTTACC \\
\hline & & & $\mathrm{BIP}(\mathrm{B} 1 \mathrm{c}+\mathrm{B} 2)$ & AATCCAACTCCATGACCACGGAGATATAGGTGATGCTGTC \\
\hline & & & Loop F & GTCCTGGGATGATATTCAC \\
\hline & & & Loop B & СTCTAACGACAGAGTATCCA \\
\hline
\end{tabular}

LAMP, loop-mediated isothermal amplification; LOD, limit of detection. 
Table 3. Bacterial species using the loop-mediated isothermal amplification and PCR

\begin{tabular}{lc}
\hline Bacterial species & Source \\
\hline Xanthomonas axonopodis pv. diffenbachiae & KACC 10317 \\
Pectobacterium atrosepticum & KACC 10463 \\
Xanthomonas campestris & KACC 10490 \\
Xanthomonas campestris pv. glycines & KACC 10491 \\
Pseudomonas syringae & KACC 10597 \\
Xanthomonas axonopodis pv. glycines & KACC 11150 \\
Burkholderia glumae & KACC 11181 \\
Burkholderia cepacia & KACC 12679 \\
Erwinia pyrifoliae & KACC 13945 \\
Erwinia rhapontici & KACC 13973 \\
Pseudomonas tolaasii & KACC 15623 \\
Pseudomonas agarici & KACC 17156 \\
Pectobacterium carotovorum subsp. brasiliense & KACC 17662 \\
Pseudomonas cichorii & KACC 18646 \\
Burkholderia gladioli & KACC 18962 \\
Pseudomonas viridiflava & KACC 19142 \\
Xanthomonas arboricola pv. pruni & KACC 19495 \\
Xanthomonas campestris pv. vitians & KACC 19681 \\
\hline
\end{tabular}

from Bioneer (Table 2).

Optimization of the XF 1535 gene LAMP assay. Twenty pM F3, B3 primer and 40 pM FIP, BIP primer, reagent $1 \times$ reaction mix (20 mM Tris- $\mathrm{HCl}\left[\mathrm{pH}\right.$ 8.8], $10 \mathrm{mM}\left(\mathrm{NH}_{4}\right)_{2} \mathrm{SO}_{4}$, $10 \mathrm{mM} \mathrm{KCl}, 2 \mathrm{mM} \mathrm{MgSO}_{4}, 0.4 \%$ Triton X-100, 6 mM MgSO
[New England Biolabs, Beverly, MA, USA], 0.8 M betaine [Sigma-Aldrich, St. Louis, MO, USA], $400 \mu \mathrm{M}$ dNTP [TaKaRa Biotechnology Co., Ltd., Tokyo, Japan]) was composed of a total of $25 \mu$ of a reaction solution. The reaction solution was allowed to stand at $95^{\circ} \mathrm{C}$ for $5 \mathrm{~min}$ on the next heat block, and then cooled on ice, and 8 unit Bst DNA polymerase large fragment (New England Biolabs) was added. After that, the reaction solution was reacted at $65^{\circ} \mathrm{C}$ for $60 \mathrm{~min}$ and $80^{\circ} \mathrm{C}$ for 10 min (Fukuta et al., 2003) and visualized by adding SYBR Green I (Life Technologies, Chicago, IL, USA). This is orange in the absence of an amplicon, and green in the presence of the LAMP amplification product.

Sensitivity and specificity. Sensitivity and specificity were tested with Xanthomonas axonopodis pv. diffenbachiae, Pectobacterium atrosepticum, $X$. campestris, $X$. campestris pv. glycines, Pseudomonas syringae, Xaxonopodis pv. glycines, Burkholderia glumae, Burkholderia cepacia, Erwinia pyrifoliae, E. rhapontic, Pseudomonas tolaasii, Pseudomonas agarici, Pectobacterium carotovorum subsp. brasiliense, Pseudomonas cichorii, Burkholderia gladioli, Pseudomonas viridiflava, $X$. arboricola pv. prun, and X. campestris pv. vitians (Table 3). DNA $\left(2.0 \times 10^{6}\right.$ copies $\left./ \mathrm{ml}\right)$ was diluted 10 times each, and the sensitivity and specificity of PCR and LAMP were tested at a concentration of $2.0 \times 10^{6}$ to $2.0 \times 10^{2}$ copies $/ \mathrm{ml}$.

\section{Results}

\section{Specificity and sensitivity of created mqsA primer} set. PCR was used to assess the specificity of the newly developed primer set. As a result of electrophoresis of the
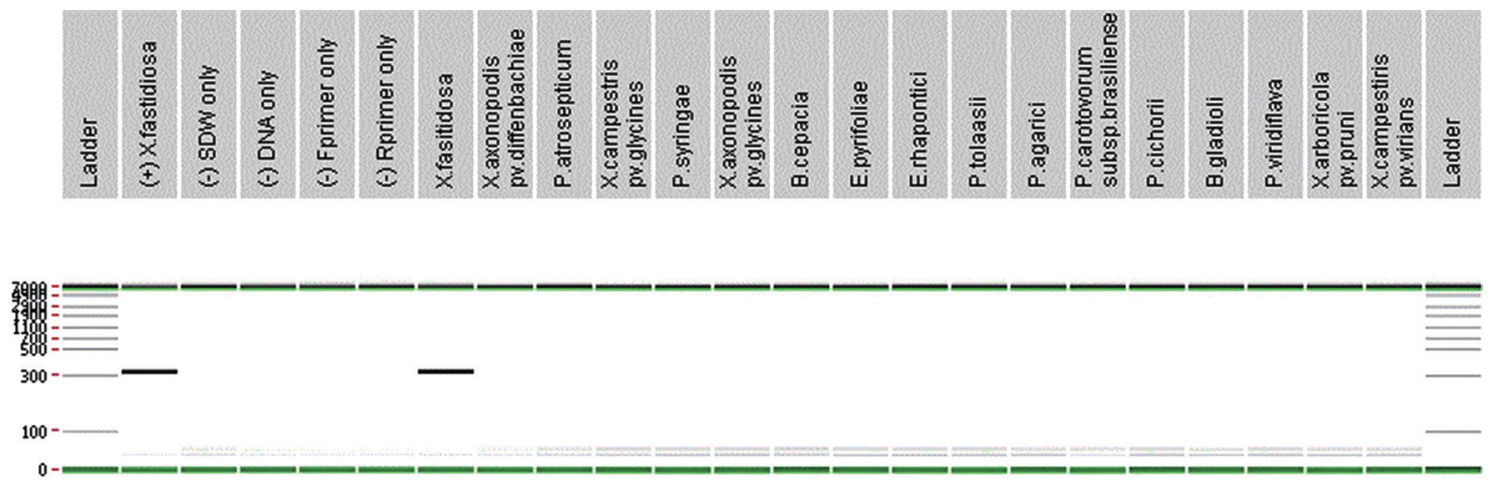

Fig. 2. Specificity of created mqsA primer set. Verification of the ability to detect Xylella fastidiosa for one type of primer (mqsA-F/mqsA-R) compared to 16 negative control strains (Korea Agricultural Culture Collection). 

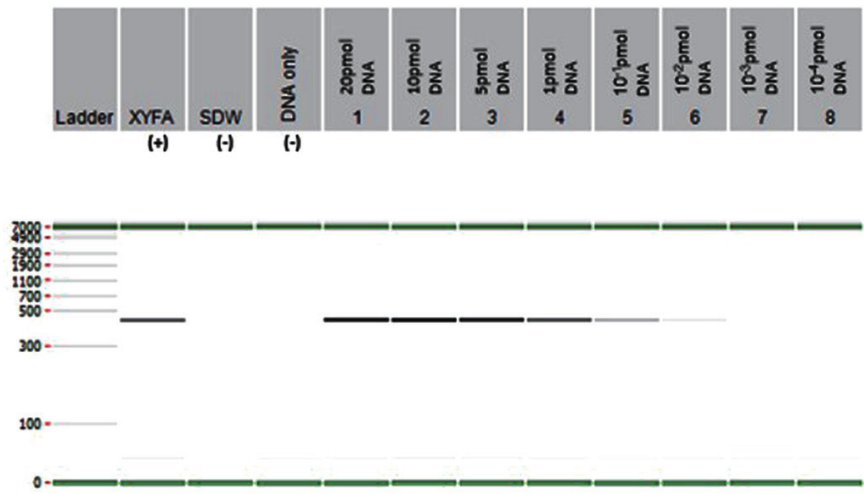

Fig. 3. Sensitivity of created mqsA primer set. Verification of detection ability by 10 times, diluted concentration of positive control.

PCR product, the amplified result was obtained only in $X$. fastidiosa, and there was no non-specific reaction with other strains (Fig. 2). The masA site contained in toxin-antitoxin is a physiological regulatory site mainly involved in pathogenicity and motility, and it is considered to be highly useful as a species-specific primer for $X$. fastidiosa. Their detection ability was confirmed according to the PCR conditions (Fig. 3). The detection capability of Pierce's disease bacteria $X$. fastidiosa was tested on 16 positive control and 16 negative control strains in total.

\section{Confirmation of specificity of LAMP method and PCR}

method. As a result of testing the specificity of LAMP PCR using standard and similar strains, only $X$. fastidiosa showed a specific reaction (Fig. 4). In the case of LAMP PCR, it is necessary to observe the time because it may cause a false-positive reaction after the standard reaction time.

\section{Confirmation of sensitivity of LAMP method and PCR}

method. After establishing the optimal conditions, the sensitivity of the LAMP detection method is determined by diluting the Streptococcus uberis culture solution to a concentration of $1.0 \times 10$ to $1.0 \times 10^{8} \mathrm{cfu} / \mathrm{ml}$, and using the Genomic DNA Extraction Kit (Bioneer) After extraction, the detection limit values of the LAMP detection method and the PCR method were compared. In the case of PCR, it can be detected only up to a concentration of $1.0 \times 10^{4} \mathrm{cfu} / \mathrm{ml}$, while as a result of measuring the detection limit of LAMP, it was confirmed that it could detect up to a concentration of $1.0 \times 10^{8}$ $\mathrm{cfu} / \mathrm{ml}$. It was confirmed that the LAMP method has a higher detection limit than the general PCR method.

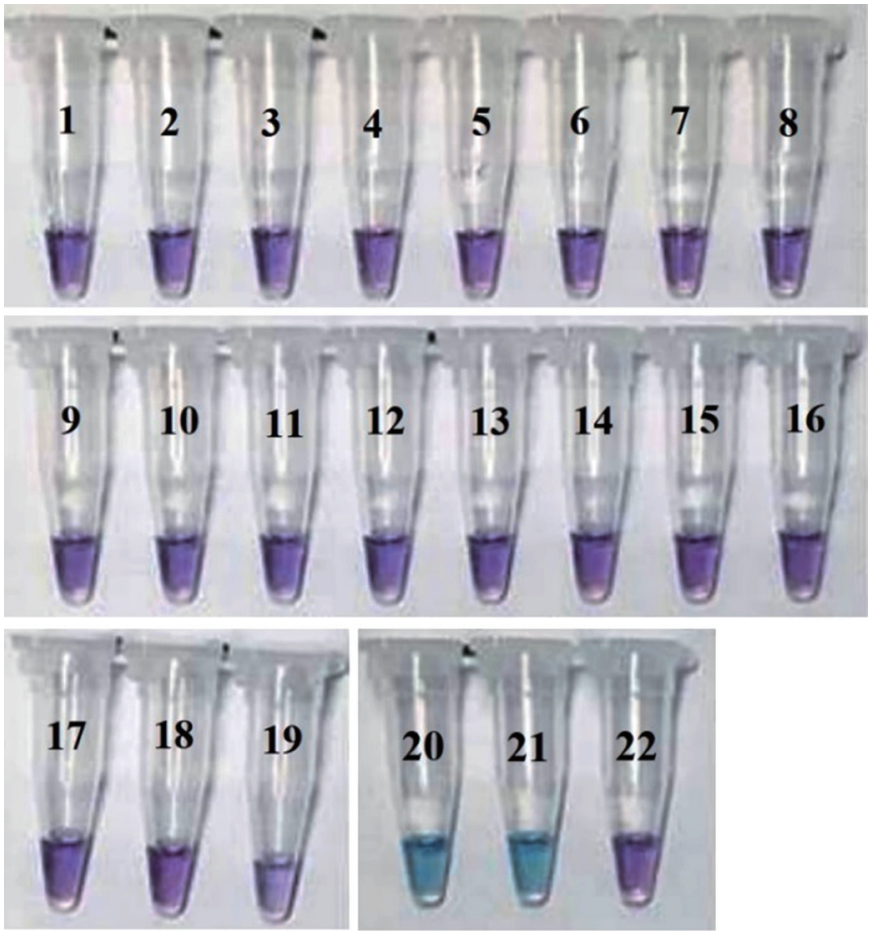

Fig. 4. Loop-mediated isothermal amplification visualized using hydroxynapthal blue dye showing the sky-blue color change (tubes 20, 21) observed with Xylella fastidiosa-positive samples. Negative samples in which no amplification occurred remain violet (tubes 1 to 19,22 ). The list of strains to be used is as follows; 1 , Xanthomonas axonopodis pv. diffenbachiae; 2, Pectobacterium atrosepticum; 3 , Xanthomonas campestris; 4, Xanthomonas campestris pv. glycines; 5 , Pseudomonas syringae; 6, Xanthomonas axonopodis pv. glycines; 7, Burkholderia glumae; 8, Burkholderia cepacia; 9, Erwinia pyrifoliae; 10, Erwinia rhapontici; 11, Pseudomonas tolaasii; 12, Pseudomonas agarici; 13, Pectobacterium carotovorum subsp. brasiliense; 14, Pseudomonas cichorii; 15, Burkholderia gladioli; 16, Pseudomonas viridiflava; 17, Xanthomonas campestris pv. vitians; 18, Xanthomonas arboricola pv. pruni; 19, negative control; 20, ATCC 700964D-5 (Xyrella fasitidiosa); 21, ATCC 35881D (Xyrella fasitidiosa); 22, negative control.

In order to measure the sensitivity of the developed LAMP, the extracted DNA was diluted 10 times in steps, and then developed LAMP and PCR were performed on the genes extracted from each dilution. It was detected that the developed LAMP was 10 times more sensitive than the existing PCR (Fig. 5).

\section{Discussion}

LAMP PCR is a technology that uses basic laboratory equipment to diagnose a variety of research products, such as infectious diseases, in the field (Chen et al., 2008). This time the 


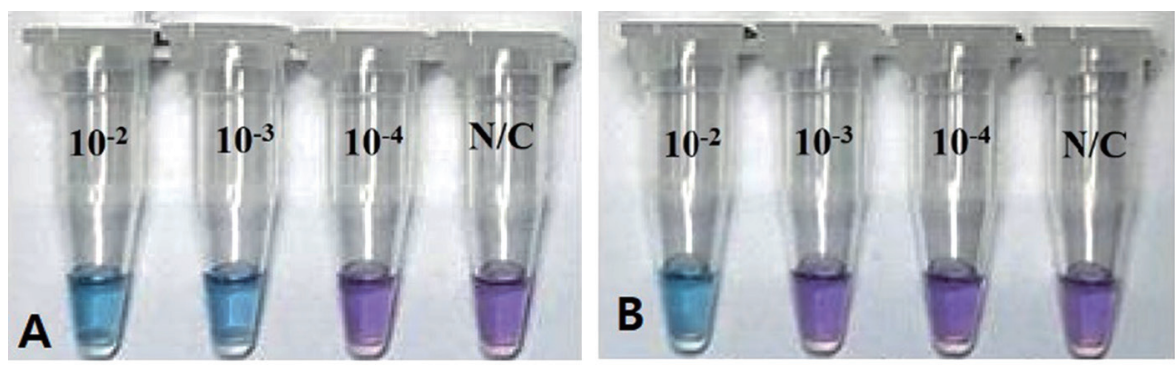

Fig. 5. Loop-mediated isothermal amplification sensitivity of Xylella fastidiosa: ATCC7000964-5 (A), ATCC35881D (B). A and B were tested up to $10^{-4}$ concentration and the photographs showed the violet to blue color change in positive samples. N/C, normal control.

LAMP PCR method was developed for use in epidemic and quarantine research. The analysis shows that there was no difference from the conventional PCR method, because of its sensitivity and specificities (Fig. 3). Consequently, the findings of this study are considered sufficient for $X$. fastidiosa diagnoses with various hosts and symptoms. It is important to observe the time in the case of LAMP PCR, since it can cause a false positive reaction after the standard reaction time. For future more reliable and effective experiments, detailed analysis of the reaction conditions and reaction reagents is necessary.

In addition, microscopy, selective medium, and PCR techniques are primarily used in the diagnosis of plant diseases. Recently, by shortening the diagnosis time and using simple diagnosis methods away from competent and complicated diagnosis methods, there is a trend to create diagnostic kits. The LAMP PCR approach is not derived and amplified by the conjugation and expansion at isothermal temperatures and has the advantage, by using mainly 4-6 primers, of increasing the PCR specificity in the target species. Since DNA amplification is possible if the temperature is kept isothermal, only an isothermal maintenance system such as a water bath and heat block can be detected without an expensive PCR device. The detection result can be tested with the naked eye when a fluorescent dye is used, so it can be used immediately in the field, and the number of applications of the diagnostic method LAMP PCR is increasing in the field.

$X$. fastidiosa is a high-risk pathogen that causes disease in a wide variety of plants. Test methods have been developed in European and Mediterranean Plant Protection Organization and others to diagnose these pathogens (Notomi et al., 2000). However, in recent years, as new genetic knowledge on pathogens has been discovered, it is important to check existing test methods and to diagnose new methods. There- fore, a new test method was developed to complement the previously developed diagnostic method. The newly developed test method detects the mas $A$ gene of $X$. fastidiosa. The findings showed high specificity and sensitivity as a consequence of checking the specificity and sensitivity of 16 related strains (Figs. 2, 3). It is important to establish a quantitative test method (real-time PCR) for more accurate testing in the future.

\section{Conflicts of Interest}

No potential conflict of interest relevant to this article was reported.

\section{References}

Berisha, B., Chen, Y. D., Zhang, G. Y., Xu, B. Y. and Chen, T. A. 1998. Isolation of Peirce's disease bacteria from grapevines in Europe. Eur. J. Plant Pathol. 104: 427-433.

Chen, J., Civerolo, E., Tubajika, K., Livingston, S. and Higbee, B. 2008. Hypervariations of a protease-encoding gene, PD0218 (pspB), in Xylella fastidiosa strains causing almond leaf scorch and Pierce's disease in California. Appl. Environ. Microbiol. 74: 36523657.

Chen, J., Groves, R., Civerolo, E. L., Viveros, A., Freeman, A. and Zheng, Y. 2005. Two Xylella fastidiosa genotypes associated with almond leaf scorch disease on the same location in California. Phytopathology 95: 708-714.

Firrao G. and Bazzi C. 1994. Specific identification of Xylella fastidiosa using the polymerase chain reaction. Phytopathol. Mediterr. 33: $90-92$.

Francis, M., Lin, H., Rosa, J. C.-L, Doddapaneni, H. and Civerolo, E. L. 2006. Genome-based PCR primers for specific and sensitive detection and quantification of Xylella fastidiosa. Eur. J. Plant Pathol. 115: 203.

Fukuta, S., lida, T., Mizukami, Y., Ishida, A., Ueda, J., Kanbe, M. et al. 2003. Detection of Japanese yam mosaic virus by RT-LAMP. 
Arch. Virol. 148: 1713-1720.

Goto, M., Honda, E., Ogura, A., Nomoto, A. and Hanaki, K.-I. 2009. Colorimetric detection of loop-mediated isothermal amplification reaction by using hydroxy naphthol blue. Biotechniques 46 : 167-172.

Hopkins, D. L. and Purcell, A. H. 2002. Xylella fastidiosa: cause of Pierce's disease of grapevine and other emergent diseases. Plant Dis. 86: 1056-1066.

Huang, Q. 2009. Specific detection and identification of Xylella fastidiosa strains causing oleander leaf scorch using polymerase chain reaction. Curr. Microbiol. 58: 393-398.

Huang, Q., Bentz, J. and Sherald, J. L. 2006. Fast, easy and efficient DNA extraction and one-step polymerase chain reaction for the detection of Xylella fastidiosa in potential insect vectors. J. Plant Pathol. 88: 77-81.

Huang, Q. and Sherald, J. L. 2004. Isolation and phylogenetic analysis of Xylella fastidiosa from its invasive alternative host, porcelain berry. Curr. Microbiol. 48: 73-76.

Leu, L. S. 1993. Isolation, cultivation, and pathogenicity of Xylella fastidiosa, the causal bacterium of pear leaf scorch disease in Taiwan. Plant Dis. 77: 642-646.

Minsavage, G. V., Thompson, C. M., Hopkins, D. L., Leite, R. M. V. B. C. and Stall, R. E. 1994. Development of a polymerase chain reaction protocol for detection of Xylella fastidiosa in plant tissue. Phytopathology 84: 456-461.
Notomi, T., Okayama, H., Masubuchi, H., Yonekawa, T., Watanabe, K., Amino, N. et al. 2000. Loop-mediated isothermal amplification of DNA. Nucleic Acids Res. 28: e63.

Pooler, M. R. and Hartung, J. S. 1995. Genetic relationships among strains of Xylella fastidiosa from RAPD-PCR data. Curr. Microbiol. 31: 134-137.

Purcell, A. H. 1997. Xylella fastidiosa, a regional problem or global threat? J. Plant Pathol. 79: 99-105.

Rodrigues, J. L. M., Silva-Stenico, M. E., Gomes, J. E., Lopes, J. R. S. and Tsai, S. M. 2003. Detection and diversity assessment of Xylella fastidiosa in field-collected plant and insect samples by using $16 \mathrm{~S}$ rRNA and gyrB sequences. Appl. Environ. Microbiol. 69: 4249-4255.

Schaad, N. W., Opgenorth, D. and Gaush, P. 2002. Real-time polymerase chain reaction for one-hour on-site diagnosis of Pierce's disease of grape in early season asymptomatic vines. Phytopathology 92: 721-728.

Tomlinson, J. and Boonham, N. 2008. Potential of LAMP for detection of plant pathogens. CAB Rev. Perspect. Agric. Vet. Sci. Nutr. Nat. Resour. 3: 66.

Wells, J. M., Raju, B. C., Hung, H.-Y., Weisburg, W. G., Mandelco-Paul, L. and Brenner, D. J. 1987. Xylella fastidiosa gen. nov., sp. nov: gram-negative, xylem-limited, fastidious plant bacteria related to Xanthomonas spp. Int. J. Syst. Bacteriol. 37: 136-143. 